\title{
PERAN LEMBAGA KESEJAHTERAAN ANAK DALAM MENANAMKAN PENDIDIKAN KARAKTER TERHADAP ANAK ASUH DI PANTI ASUHAN
}

\author{
Winda Anggunita Lestari \\ FKIP Universitas Muhammadiyah Malang, Indonesia \\ Email: Windaanggunita13@gmail.com
}

\begin{abstract}
This study aims to: 1) Know the implementation of character education; 2) Identify supporting and inhibiting factors in the implementation of character education; 3) Unveil solutions to overcome obstacles faced in the implementation of character education at Nurul Hidayah Orphanage. Approach and type of research used is descriptive qualitative with kind of field research. Research location one month research. Data collection techniques used are observation, interview and documentation study. Analytical technique using Milles and Huberman model with technique of validity of data of credibility, transferability, dependability, and confirmability. Based on the research results obtained as follows: 1) Character Education at NurulHidayah Orphanage has been strived to develop intellectual and spiritual intelligence with different backgrounds of parenting. 2) Supporting factors in the implementation of Character Education at NurulHidayah Orphanage are: While the inhibiting factors are: the tendency of caregivers to take care of limited to the level of cognitive and religious only; there are still some caregivers who subordinate character education; the varying character of each child and the lack of recognition of the caregiver of each character; and there are still violations of regulations in the Orphanage. 3) Solutions in overcoming the obstacles that occur are: through the direction and evaluation of all Orphanage management; spiritual guidance and counseling; control of the child's intercourse synergistically by the carer.
\end{abstract}

Keywords: Child Welfare Institution; Character Education; Foster Children; Orphanage

\section{PENDAHULUAN}

Pada dasarnya manusia terlahir hanya membawa "personality" atau kepribadian, setiap orang mempunyai kepribadian yang berbeda-beda, setiap kepribadian memiliki kelemahan dan keungulan masing-masing dan kepribadian bukanlah suatu karakter setiap manusia, dalam mengatasi masalah dan memperbaiki kelemahanya yang akan memunculkan kebiasaan positif yang baru, maka inilah yang disebut dengan karakter.

Persoalan pendidian karakter secara umum sejauh ini bisa disebut juga sebagai pendidikan moral, sejauh ini pendidkan karakter tersebut dapat dalam aplikasinya terlalu membentuk satu arah pembelajaran khusus sehingga memerlukan pembelajaran lainnya dalam membentuk sudut kurikulum, perbaikan sumber daya manusia yang cerdas, terampil, madiri dan beraklak mulia terus diupayakan melalui proses pendidikan karakter itu sendiri.

Pendidikan karakter penting bagi panti asuhan. Pendidikan karakter akan menjadi dasar atau dasar dalam pembentukan karakter berkualitas, yang tidak mengabaikan nilai-nilai sosial seperti toleransi, kebersamaan, kegotong royongan, saling membantu dan mengormati dan sebagainya. Pendidikan karakter akan melahirkan pribadi unggul yang tidak hanya memiliki kemampuan kognitif saja namun memiliki karakter yang mampu mewujudkan kesuksesan. Berdasarkan penelitian di Harvard University Amerika Serikat, ternyata kesuksesan seseorang tidak semata-mata ditentukan oleh pengetahuan dan kemampuan teknis dan kognisinyan (hard skill) saja, tetapi lebih oleh kemampuan mengelola diri dan orang lain (soft skill). 
Penelitian ini mengungkapkan, kesuksesan hanya ditentukan sekitar 20 persen hard skill dan sisanya 80 persen oleh soft skill dan kecakapan soft skill ini terbentuk melalui pelaksanaan pendidikan karater pada anak didik. Berpijak pada empat ciri dasar pendidikan karakter, untuk bisa menerapkannya dalam pola pendidikan yang diberikan pada anak asuh.

T.Ramli (2003) menyatakan penanganan masalah kesejahteraan sosial anak terlantar melalui sistem panti adalah dimana pola asuhan diberikan kepada anakanak yang terlantar. Pola asuhan dalam panti adalah sebagai pengganti orang tua bagi anak yang terlantar sehingga anak merasa terjamin hidup. Dimana pelayanan yang diberikan berupa penyediaan fasilitas pemenuhan kebutuhan sandang, pangan, pendidikan, bimbingan rohani serta keterampilan dimana diharapkan anakanak tersebut dapat mengembangkan pribadi, potensi, kemampuan dan minatnya secara optimal. Sedangkan asuhan nonpanti adalah asuhan secara berkelompok dalam rumah bagi anak-anak remaja yang tidak dapat menyesuaikan diri dengan keluarga asuhnya.

Panti Nurul Hidayah merupakan suatu badan atau lembaga kesejahteraan sosial yang merupakan keluarga pengganti sekaligus tempat tinggal bagi anak-anak asuh. Panti asuhan dengan sistem pelayanan yang ada di dalamnya merupakan suatu proses bagi anak-anak asuh dimana anak panti asuhan mendapatkan bimbingan dan asuhan yang seharusnya mereka dapatkan dari keluarga, khususnya orang tua.

Dengan kata lain upaya dalam pembaharuan pendidikan karakter meliputi hal-hal yang diusahakan untuk peningkatan kualitas pendidikan karakter pada panti asuhan seperti yang dikemukakan oleh Misbah (1978) antara lain : 1) Masalah pemerataan pendidikan, 2) Masalah relevansi pendidikan dengan tuntutan masyarakat, 3) Masalah kualitas/mutu pendidikan di dalam panti, 4) Masalah efesiensi pendidikan karakter pada anak panti.

\section{METODE}

Penelitian ini bersifat kualitatif, menurut moleong (2012) penelitian kualitatif adalah penelitian yang dimaksud untuk memehami fenomena yang di alami oleh subjek penelitian, misalnya: 1) perilaku 2) persepsi 3) motivasi dan 4) tindakan dengan cara deskriptif dalam bentuk kata-kata dan bahasa dalam suatu konteks khusus yang dialami dan di manfaatkan sebagai metode ilmiah.

Jenis penelitian yang digunakan adalah penelitian lapangan. Penilitian lapangan dapat juga dianggap pendekatan luas dalam penelitian kualitatif atau sebagai metode untuk mengumpulkan data kualitatif. Ide pentingnya adalah bahwa peneliti berangkat ke lapangan untuk mengadakan pengamatan untuk suatu fenomena dalam suatu keadaan ilmiah jenis penelitian yang digunakan adalah jenis penelitian yang menghasilkan katakata tertulis atau lisan dari orang-orang dan datanya dikumpulkan berupa tulisan katakata, gambar dan bukan angka-angka. Jadi selama proses penelitian ini, peneliti akan lebih banyak berhubungan atau ngadakan kontak dengan subjek penelitian di panti asuhan Nurul Hidayah.

Menurut Zuriah (2009) penelitian deskriptif adalah penelitian yang berusaha memberikan gambaran sistematis serta memberika gambaran fakta-fakta aktual serta sifat-sifat populasi tertentu, secara spesifik, peneliti deskriptif memiliki ciri-ciri sebagai berikut: 1) bertujuan untuk memecahkan masalah aktual yang dihadapi sekarang; 2) bertujuan untuk mengumpulkan data atau informasi untuk disusun, dijelaskan dan dianalisis dan 3) penelitian ini biasanya tanpa hipotesis biasaya tidak diuji untuk analisis statistik. 


\section{HASIL DAN PEMBAHASAN}

\section{Implentasi Pendidikan Karakter Didalam Panti Asuahn Nurul Hidayah}

Berdasarkan hasil wawancara tentang pemahaman pendidikan karakter pada anak panti asuhan, didapatkan bahwa hanya sebagian anak yang memahami pendidikan karakter secara teoritis. Panti Asuhan dalam hal ini harus berupaya dalam menanamkan pemahaman pendidikan karakter kepada anak baik secara teoritis maupun secara praktis.

Menanamkan pendidikan karakter pada anak tidak hanya dengan teoritis saja, tetapi juga harus dengan contoh praktis. Nilai-nilai pendidikan karakter sudah termaktub dalam 18 nilai karakter yang dikembangkan oleh pemerintah. Contoh tauladan dan contoh-contoh sikap bagaimana bertindak, bertutur kata, berkebiasaan, beradab dalam kehidupan baik di sekolah maupun di lingkungan tempat tinggal menjadi hal terpenting di samping penanaman dan pemahaman nilai-nilai karakter tersebut. Hal ini harus ditanamkan kepada seluruh anak, sehingga mereka dapat memahami dan ikut membiasakan diri dalam tindakan berkarakter.

Pendidikan karakter tidak dapat dipisahkan umumnya pendidikan karakter di Indonesia tidak dikembangkan secara menyeluruh di lingkungan sosial. Pendidikan karakter hanya dilakukan secara parsial baik itu hanya pada tataran intelektual, emosional, atau bahkan pada tataran spiritualnya saja. Padahal hal ini perlu dibentuk hubungan sinergis sehingga dapat menghasilkan manusia yang seutuhnya. Pendidikan karakter tentunya harus simbang antara aspekisi, metode, proses, subjek, evaluasi.

Penelitian ini peneliti mendapatkan bahwa pendidikan karakter didalam panti asuhan mendapatkan bahwa pendidikan karakter yang ditanamkan di dalam panti asuhan Nurul Hidayah sudah mencangkup seluruh aspek dari nilai-nilai pokok karakter, hal tersebut dapat dibuktikan dengan pada saat peneliti melakukan penelitian sudah ditanamkanya nilai-nilai karakter dalam setiap kegiatan sehari-hari.

\section{Faktor Pendukung dan Penghambat dalam Implementasi Pendidikan Karakter di dalam Panti Asuhan Nurul Hidayah}

Pendidikan karakter didalam panti asuhan Nurul Hidayah tentunya sudah berjalan namun dalam perkembangannya tentu tidak bisa terlepas dari adanya dukungan dan hambatan yang terjadi.

Berdasarkan hasil wawancara, observasi, dan dokumentasi dapat dianalisis bahwa faktor pendukung implementasi pendidikan karakter di Panti Asuhan Nurul Hidayah adalah: 1) komitmen antara Panti Asuhan dan Pengurus Panti; 2) faktor pengurus panti asuhan yang berkompeten dalam pendidikan karakter dan religius baik iptek dan imtaknya; 3) tata tertib panti asuhan yang dijalankan secara konsisten; 4) Pengasuh yang selalu membuka diri dalam konseling tidak pasif dalam menanamkan nilai-nilai karakter; 5) sinergi yang baik antar subjek pendidik (sekolah, orang tua, pemerintah dan dinas sosial); dan 6) sarana-prasarana yang menunjang untuk melakuakan proses pendidikan karakter.

Sedangkan faktor penghambat implementasi pendidikan karakter di Panti Asuhan Nurul Hidayah, diantaranya: 1) kecenderungan pengurus melakukan pengasuhan sebatas pada tataran kognitif dan kereligiusan saja; 2) masih adanya beberapa pengasuh yang menomor duakan pendidikan karakter; 3) faktor lingkungan sosial beberapa siswa yang kurang baik di selolah salah bergaul dan diluar lingkungan panti asuhan; 4) beragamnya karakter setiap anak dan kurang mengenalnya pengasuh terhadap karakter masing - masing secara lebih mendalam; 5) salah pemanfaatan teknologi oleh setiap anak; dan 6) Masih terdapatnya pelanggaran peraturan di panti 
asuhan. Sehingga hal-hal tersebut diatas menjadi faktor penghambat terjadinya penanaman dan pembiasaan nilai karakter pada anak di Panti Asuhan Nurul Hudayah.

Solusi untuk Mengatasi HambatanHambatan yang dihadapi dalam Implementasi Pendidikan Karakter Didalam Panti Asuhan Nurul Hudayah

Setiap hambatan-hambatan yang terjadi tentunya perlu dicari jalan penyelesaianyang terbaik. Begitu pula dalam implementasi pendidikan karakter di Panti Asuhan Nurul Hidayah, diantaranya dengan mengadakan evaluasi kepada pengasuh panti asuhan agar dalam membentuk karakter anak dapat dilakukan secara maksimal. Sehingga dalam proses belajar pendidikan karakter yang di tanamkan pengurus tidak hanya terfokus pada ranah kognitif, religius dan kepribadian nak didalam panti asuhan setiap harinya saja namun perlu dilakukan secara meyeluruh.

Solusi dalam upaya memperbaiki kepribadian anak perlu adanya kontrol melalui observasi, konsultasi dengan setiap pengurus panti asuhan. Selain hubungan intern di dalam panti tentunya perlu sumbangsih dari seluruh sumber daya manusianya di dalam panti asuhan ini dalam upaya mengontrol anak. Sehingga anak dan pengurus pantiasuhan harus bekerjasama secara baik. Solusi lain adalah melalui program kepribadian dan pemupukan pendidikan keagamaan secara menyeluruh, meskipun sesungguhnya dalam setiap membimbing dan mengasuh juga melakukan hal yang sama dengan ketika kegiatan setiap hari dilakukan.

Solusi lain yang sifatnya kondisional dapat dilakukan pengasuhan dan bimbingan dari luar oleh pengajar yang berkompeten dibidangnya. Lalu anak-anak merenung bersama. Meski sesungguhnya disetiap pengasuhan dan pelajaran dilakukan hal yang pelatihan pendidikan karakter yang religius (merenungkan keagungan
Tuhan, berdzikir) agar mereka tersentuh dan lebih tawadu'. Hasil wawancara juga diperkuat dengan hasil observasi dan stu di dokumentasi di lapangan sebagai berikut: 1)pengarahan dan efaluasi seluruh pengurus panti asuhan sehingga dalam kegiatan pengasuhan tidak hanya terfokus pada intelektualitas anak tetapi juga pada pembentukan karakter anak itu sendiri; 2) melalui bimbingan rohani dan koserling, biasanya dilakukan komunikasi antara anak dan pengurus panti; 3) kontrol pergaulan anak secara sinergis oleh pengasuh; 4) konsistensi dan koreksi kegiatan yang telah dilaksanakan baik dalam kegiatan pengasuhan maupun hubungan dengan seluruh subjek pengajar.

\section{SIMPULAN}

Pendidikan Karakter di dalam panti asuhan Nurul Hidayah telah diupayakan untuk mengembangkan kecerdasan intelektual dan spriritual dengan latar belakang pola asuh yang berbeda- beda, kecerdasan emosional setiap anak di dalam panti asuhan dalam menyikapi diri dan keadaan di dalam panti asuhan dalam pola asuh pengurus panti. Selain itu pendidikan karakter dilakukan dengan cara memberikan wawasan secara luas sehingga mampu menerimadengan baik seluruh aspek dan ruang lingkup dari segi isi pendidikan karakter, metode pendidikan karakter, proses pendidikan karakter, subjek pendidik dan evaluasi, hal ini tergambar dari: 1) sholat tahajud dan solat subuh setiap hari secara berjamaah ; 2) gotong royong membersihkan lingkungan panti asuhan; 3) doa bersama dan istigosah; 4) Solat magrib dan isak serta kajian keislaman; 5) selalu merayakan hari besar keagaaman, misalnya idul adha; 6) Membentuk kelompok belajar; 7) Mengaji atau qataman Al'quran; 8) berkebun di green house.

Faktor pendukung dalam Implementasi Pendidikan Karakter di dalam panti asuhan Nurul Hidayah adalah: 1) komitmen antara panti asuhan 
dan pengurus panti; 2) faktor pengurus panti asuhan yang berkompeten dalam pendidikan karakter yang religius baik iptek maupun imtaknya; 3) tata tertib yang dijalankan secara konsisten; 4) Pengasuh yang selalu membuka diri dalam konseling tidak pasif dalam menanamkan nilai-nilai karakter; 5) sinergi yang baik antar subjek pendidik (sekolah, orang tua, pemerintah dan dinas sosial); dan 6) sarana-prasarana yang menunjang untuk melakukan proses pendidikan karakter. Sedangkan faktor penghambat pendidikan karakter di dalam panti asuhan nurul hidayah adalah: 1) kecenderungan pengurus melakukan pengasuhan sebatas pada tataran kognitif dan kereligiusan saja; 2) masih adanya beberapa pengasuh yang menomor duakan pendidikan karakter; 3) faktor lingkungan sosial beberapa siswa yang kurang baik di selolah salah bergaul dan diluar lingkungan panti asuhan; 4) beragamnya karakter setiap anak dan kurang mengenalnya pengasuh terhadap karakter masing-masing secara lebih mendalam; 5) salah pemanfaatan teknologi oleh setiap anak; dan 6) Masih terdapatnya pelanggaran peraturan di panti asuhan. Sehingga hal-hal tersebut diatas menjadi faktor penghambat terjadinya penanaman dan pembiasaan nilai karakter pada anak di Panti Asuhan Nurul Hudayah.

Solusi dalam mengatasi hambatanhambatan yang terjadi dalam Implementasi Pendidikan Karakter di panti asuhan Nurul Hidayah adalah: 1)pengarahan dan efaluasi seluruh pengurus panti asuhan sehingga dalam kegiatan pengasuhan tidak hanya terfokus pada intelektualitas anak tetapi juga pada pembentukan karakter anak itu sendiri; 2) melalui bimbingan rohani dan koserling, biasanya dilakukan komunikasi antara anak dan pengurus panti; 3) kontrol pergaulan anak secara sinergis oleh pengasuh; 4) konsistensi dan koreksi kegiatan yang telah dilaksanakan baik dalam kegiatan pengasuhan maupun hubungan dengan seluruh subjek pengajar.

\section{DAFTAR PUSTAKA}

Anisa, R. 2014. Kesejahteraan Siswa pada Keluarga Pra Sejahtera. Skripsi. Universitas Muhammadiyah Surakarta: Fakultas Psikologi

Mazaya, K. N., \& Supradewi, R. 2011. Konsep Diri dan Kebermaknaan Hidup Pada Remaja di Panti Asuhan. Proyeksi, Vol.6 hal 110.

Sarwono, S. N. (2014). Kasus Panti Asuhan, Sebab dan Akibat. http:// www.kompas.co.id/. Diakses tanggal 1 Oktober 2015 pukul 10.58 WIB.

Sudrajat, T. 2008. Kurangnya Pengasuhan di Panti Asuhan. https://www. kemsos.go.id/ Diakses tanggal 1 Oktober 2015 pukul 10.58 WIB.

Sugiyono. 2013. Metode Penelitian Kuantitatif Kualitatif dan $R \& D$. Bandung: Alfabeta

Undang-Undang Republik Indonesia Nomor 20 Tahun 2003 Tentang Sistem Pendidikan Nasional.

Undang-undang Republik Indonesia Nomor 23 Tahun 2002 tentang Perlindungan Anak.

Zuriah, Nuzul. 2009. Metodologi Penelitian Sosial Pendidikan Teori-Aplikasi. Jakarta: PT Bumi Aksara. 